ScIDice

\section{Prevalence Of Periodontitis In Patients With Cardiac Disorders Reporting To A University Hospital Setup}

Jitesh.S ${ }^{1}$, Arvina Rajasekar ${ }^{2 *}$, Madhulaxmi M ${ }^{3}$

${ }^{1}$ Saveetha Dental College, Saveetha institute of medical and technical sciences (SIMATS), Saveetha university, Chennai, India.

${ }^{2}$ Senior Lecturer, Department of Periodontics, Saveetha Dental College and Hospitals, Saveetha Institute of Medical and Technical Sciences, Saveetha University, Chennai, India.

${ }^{3}$ Professor, Department of Oral and Maxillofacial Surgery, Saveetha Dental College and Hospitals, Saveetha Institute of Medical and Technical Sciences, Saveetha University, Chennai, India.

\title{
Abstract
}

\begin{abstract}
Periodontitis is a chronic inflammatory disease affecting periodontal tissues. During periodontal disease, several chronic inflammation markers rise. Since it was believed that Cardiovascular disorder has an etiological origin, the presence of an etiological relationship between periodontal disease and CVD has been considered for years.It was reported recently that chronic inflammation plays an important role in cardiovascular disease (CVD) etiology. Periodontitis is a chronic inflammatory disease affecting periodontal tissues. During periodontal disease, several chronic inflammation markers rise.The main aim of this study was to find out the prevalence of periodontitis in patients with cardiac disorder visiting Saveetha dental college and hospitals. The present retrospective study was conducted among 100 outpatients with cardiac disorders who reported to Saveetha Dental College and Hospitals, Chennai from June 2019 to March 2020. Data regarding the periodontal status was collected and analysed. The present study showed among 100 cardiac disorder patients, $41 \%$ of them had gingivitis and $59 \%$ had periodontitis. There was no significant association between gender and periodontal disease. ( $\mathrm{p}$ value $=0.06(>0.05)$; statistically not significant). Within the limitations of the present study, periodontitis was more prevalent in patients with cardiac disorders and there was no significant association between gender and periodontal disease.
\end{abstract}

Keywords: Atherosclerosis; Cardiac Disorders; Periodontium; Periodontitis.

\section{Introduction}

The relationship between oral and systemic diseases has been discussed frequently in recent years. In many studies, this relationship was focused mainly on periodontal diseases [39, 14, 38, 27 , 28]. Cardiovascular diseases rank first among the causes of death in developed countries. About 7 million people die from conditions caused by cardiovascular diseases worldwide [15]. Several factors are defined among the causes of cardiovascular diseases; however, a significant portion of these can not be described with traditional risk factors $[19,38,18,1]$.

It was reported recently that chronic inflammation plays an important role in cardiovascular disease (CVD) etiology. Periodontitis is a chronic inflammatory disease affecting periodontal tissues. During periodontal disease, several chronic inflammation markers rise. Since it was believed that CVD has an etiological origin, the presence of an etiological relationship between periodontal disease and CVD has been considered for years [32]. Thus, a number of studies on the possibility of periodontal disease causing CVD were carried out and a relationship between periodontal disease and CVD was established [16, 3, 4, 25]. Periodontal pathogens were associated with atherosclerosis [23, 2] and coronary heart disease in seroepidemiological studies [24, 10, 11, 22].

Periodontal diseases are chronic diseases that occur as a consequence of interaction between bacteria and host, leading to inflammation and damage in the hard and soft supporting tissues of the tooth $[8,16,37,9]$. Chronic periodontitis is the most common periodontal disease associated with systemic diseases [26]. Although approximately $50 \%$ of the adult population over the age of 50 have periodontitis, the damaging effect of this inflam-

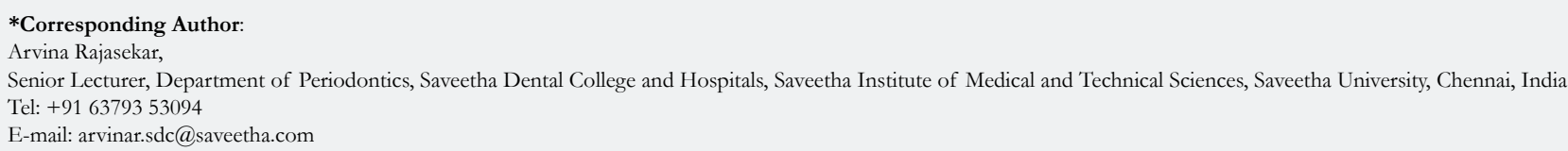

Citation: Jitesh.S, Arvina Rajasekar, Madhulaxmi M. Prevalence Of Periodontitis In Patients With Cardiac Disorders Reporting To A University Hospital Setup. Int J Dentistry Oral Sci. 2020;S7:02:008:33-36. doi: http://dx.doi.org/10.19070/2377-8075-SI02-07008

Copyright: Arvina Rajasekar 2020 . This is an open-access article distributed under the terms of the Creative Commons Attribution License, which permits unrestricted use, distribution and reproduction in any medium, provided the original author and source are credited. 
matory process displays individual variations $[13,21,27,30,29]$.

Complex genetic and environmental factors cause cardiovascular diseases such as atherosclerosis and myocardial infarction [7]. Genetic factors include age, obesity, diabetes and hypertension. Environmental factors include smoking, diet, socio-economic status and exercise. Smoking, hypercholesterolemia and hypertension, classic risk factors, exist in one-third to two-thirds of cases. [34]. It is believed that genetic factors play a role in approximately half of the cases with periodontitis [17]. Research suggests that inflammation plays an important role in the pathogenesis of both diseases. Elevation of systemic markers is considered among the risk factors for CVD [20].

In this context, the present study was undertaken to find the prevalence of periodontitis in patients with cardiac disorders among the Chennai population.

\section{Materials And Methods}

This retrospective study was undertaken using a convenience sample of patients with cardiac disorder reported to Saveetha Dental College and Hospitals, Chennai from June 2019 to March 2020. The study consisted of a total of 100 patients including 73 males and 27 females. Data regarding their periodontal status was collected and was assessed. Ethical approval for the study was obtained from Saveetha University Ethical Review Board(SDC/ SIHEC/2020/DIASDATA/0619-0320).

\section{Results And Discussion}

Data collected were entered in SPSS version 20 and was subjected to statistical analysis. Results were tabulated and represented graphically.
Out of 100 patients, $73 \%$ were males and 27\% were females. (Figure 1) Regarding the periodontal status of the cardiac disorder patients, 59\% had periodontitis and $41 \%$ had gingivitis. (Figure 2). There was no significant association between gender and periodontal disease. (Pearson-3.474, DF:1, Chi-Square test $\mathrm{p}=0.06$ $(>0.05)$; statistically not significant) (Figure 3).

In the present study, 59\% had periodontitis and $41 \%$ had gingivitis. Similar results were observed in previous studies. Stewart R et al suggested that there is an increasing evidence for an association between periodontitis and cardiovascular disorders (36). Sanz M et al assessed the relationship between periodontitis and cardiovascular disorders and claimed in his consensus report that there is a strong association between periodontitis and cardiovascular disorders [33].

Kizildag A et al studied the relationship between periodontitis and cardiovascular disorders and reported inflammatory markers were increased in both periodontitis and cardiovascular disorders suggesting statistically significant association [12]. Our findings are in agreement with the previous studies as the prevalence of periodontitis was higher in the studied population.

In our present study there was no significant association between gender and periodontal disease whereas Eke PI et al documented that there was significant relationship between gender and periodontitis and it was more prevalent in males than females which contradicts our study [5]. Harlan J Shiau et al suggested that men appear at greater risk for destructive periodontal disease than women; however, men do not appear at higher risk for more rapid periodontal destruction than women [35]. Ekr PI et al suggested that analysis is limited to the severe periodontitis category, men are at higher risk compared to women [6].

Figure 1. Bar chart depicts the gender distribution of the present study. X-axis represents the gender and Y-axis represents the percentage of the study population. Brown colour denotes males which was about $73 \%$ and pink colour denotes females which was about $27 \%$.

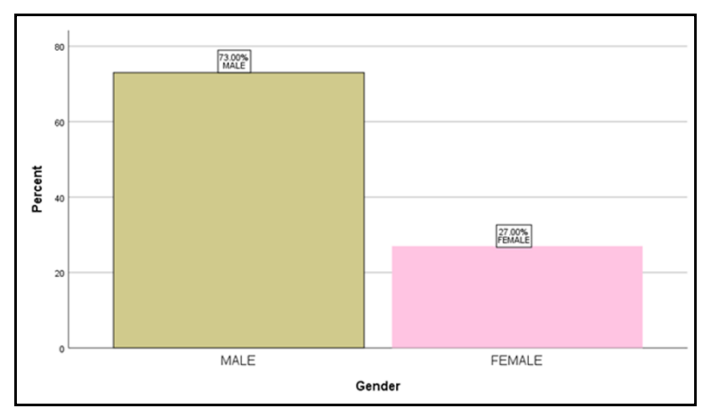

Figure 2. Bar chart depicts the distribution of periodontal disease in the present study where blue colour denotes periodontitis $(59 \%)$ and red colour denotes gingivitis $(41 \%) . \mathrm{X}$ axis represents the periodontal disease status and $\mathrm{Y}$ axis represents the percentage of the study population.

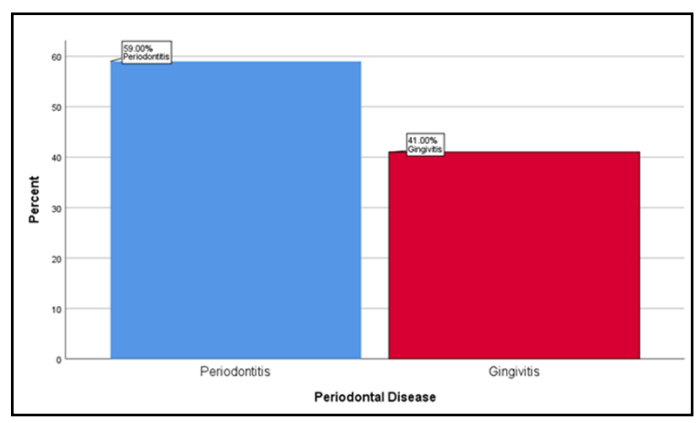


Figure 3. Bar chart depicts the association between gender and periodontal disease. $\mathrm{X}$-axis represents the gender and Y-axis represents the percentage distribution of study population. More numbers of males had periodontitis compared to females. Chi-Square test was done and association was found to be statistically not significant. Pearson - 3.474, DF:1, Chi-Square test $\mathrm{p}=0.06(>0.05)$; statistically not significant showing that there was no association between gender and periodontal disease in patients with cardiac disorders.

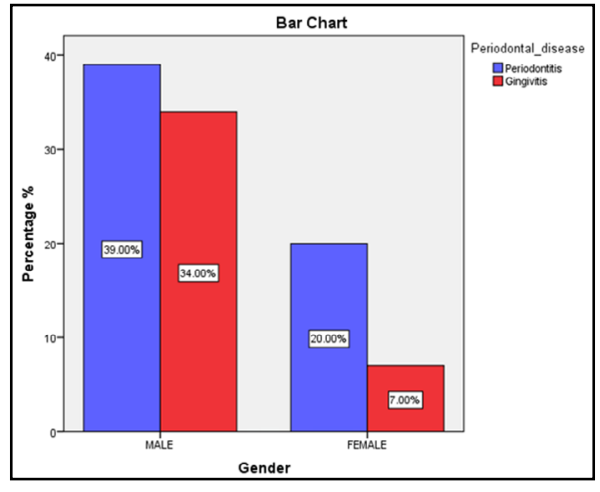

The limitation of this study is its smaller sample size. A similar study should be conducted on a larger scale involving a large number of samples for more reliable results. Therefore, extensive studies need to be conducted to assess the association between cardiac disorders and periodontal diseases.

\section{Conclusion}

Within the limitations of the present study, periodontitis was more prevalent in patients with cardiac disorders and there was no significant association between gender and periodontal disease in patients with cardiac disorders.

\section{Acknowledgement}

The authors of this study would like to express their gratitude towards everyone who facilitated and enabled us to carry out this study successfully.

\section{Author Contributions}

Jitesh.S performed the analysis, interpretation and wrote the manuscript. Second author Arvina Rajasekar contributed to conception, data design, analysis, interpretation and critically revised the manuscript. Madhulaxmi M participated in the study and revised the manuscript. All the three authors have discussed the results and contributed to the final manuscript.

\section{References}

[1]. Avinash K, Malaippan S, Dooraiswamy JN. Methods of Isolation and Characterization of Stem Cells from Different Regions of Oral Cavity Using Markers: A Systematic Review. Int J Stem Cells. 2017 May 30;10(1):12-20. Pubmed PMID: 28531913.

[2]. Beck JD, Eke P, Lin D, Madianos P, Couper D, Moss K, et al. Associations between IgG antibody to oral organisms and carotid intima-medial thickness in community-dwelling adults. Atherosclerosis. 2005 Dec;183(2):3428. Pubmed PMID: 15893320.

[3]. Beck JD, Offenbacher S. Oral health and systemic disease: periodontitis and cardiovascular disease. J Dent Educ. 1998 Oct;62(10):859-70. Pubmed PMID: 9847889.

[4]. Buhlin K, Gustafsson A, Pockley AG, Frostegård J, Klinge B. Risk factors for cardiovascular disease in patients with periodontitis. European heart journal. 2003 Dec 1;24(23):2099-107.

[5]. Eke PI, Dye BA, Wei L, Slade GD, Thornton-Evans GO, Borgnakke WS, et al. Update on Prevalence of Periodontitis in Adults in the United States: NHANES 2009 to 2012. J Periodontol. 2015 May;86(5):611-22. Pubmed PMID: 25688694.

[6]. Eke PI, Wei L, Thornton-Evans GO, Borrell LN, Borgnakke WS, Dye B, Genco RJ. Risk indicators for periodontitis in US adults: NHANES 2009 to 2012. Journal of periodontology. 2016 Oct;87(10):1174-85.

[7]. Herzberg MC, Meyer MW. Dental plaque, platelets, and cardiovascular diseases. Annals of periodontology. $1998 \mathrm{Jul} ; 3(1): 151-60$.

[8]. Jackson VP, Harrill CD, White SJ, Gillespie KR, Mail JT, Katz BP. Evaluation of a dual-screen, dual-emulsion mammography system. AJR Am J Roentgenol. 1989 Mar;152(3):483-6. Pubmed PMID: 2783800.

[9]. Kavarthapu A, Thamaraiselvan M. Assessing the variation in course and position of inferior alveolar nerve among south Indian population: A cone beam computed tomographic study. Indian J Dent Res. 2018 JulAug;29(4):405-409. Pubmed PMID: 30127186.

[10]. Khalid W, Vargheese SS, Lakshmanan R, Sankari M, Jayakumar ND. Role of endothelin-1 in periodontal diseases: A structured review. Indian J Dent Res. 2016 May-Jun;27(3):323-33. Pubmed PMID: 27411664.

[11]. Khalid W, Varghese SS, Sankari M, Jayakumar ND. Comparison of Serum Levels of Endothelin-1 in Chronic Periodontitis Patients Before and After Treatment. J Clin Diagn Res. 2017 Apr;11(4):ZC78-ZC81. Pubmed PMID: 28571268

[12]. Kizildag, A. (2014) 'Relationship between periodontitis and cardiovascular diseases: A literature review', World Journal of Stomatology, p. 1. doi: 10.5321/wjs.v3.i1.1.

[13]. Löe H, Anerud A, Boysen H, Morrison E. Natural history of periodontal disease in man. Rapid, moderate and no loss of attachment in Sri Lankan laborers 14 to 46 years of age. J Clin Periodontol. 1986 May;13(5):431-45. Pubmed PMID: 3487557.

[14]. Loos BG, Craandijk J, Hoek FJ, Wertheim-van Dillen PM, van der Velden U. Elevation of systemic markers related to cardiovascular diseases in the peripheral blood of periodontitis patients. J Periodontol. 2000 Oct;71(10):1528-34. Pubmed PMID: 11063384.

[15]. Mackay, J., Mensah, G. A. and World Health Organization (2004) The Atlas of Heart Disease and Stroke. World Health Organization.

[16]. Mattila KJ, Nieminen MS, Valtonen VV, Rasi VP, Kesäniemi YA, Syrjälä SL, et al. Association between dental health and acute myocardial infarction. BMJ. 1989 Mar 25;298(6676):779-81. Pubmed PMID: 2496855.

[17]. Michalowicz BS, Diehl SR, Gunsolley JC, Sparks BS, Brooks CN, Koertge TE,et al. Evidence of a substantial genetic basis for risk of adult periodontitis. J Periodontol. 2000 Nov;71(11):1699-707. Pubmed PMID: 11128917.

[18]. Mootha A, Malaiappan S, Jayakumar ND, Varghese SS, Toby Thomas J. The Effect of Periodontitis on Expression of Interleukin-21: A Systematic Review. Int J Inflam. 2016;2016:3507503. Pubmed PMID: 26998377.

[19]. Panda S, Jayakumar ND, Sankari M, Varghese SS, Kumar DS. Platelet rich fibrin and xenograft in treatment of intrabony defect. Contemp Clin Dent. 2014 Oct;5(4):550-4. Pubmed PMID: 25395778.

[20]. Pearson TA, Mensah GA, Alexander RW, Anderson JL, Cannon RO 3rd, Criqui M, et al; Centers for Disease Control and Prevention; American Heart Association. Markers of inflammation and cardiovascular disease: application to clinical and public health practice: A statement for healthcare professionals from the Centers for Disease Control and Prevention and the American Heart Association. Circulation. 2003 Jan 28;107(3):499-511. Pubmed PMID: 12551878.

[21]. Pihlstrom BL, Michalowicz BS, Johnson NW. Periodontal diseases. Lancet. 
2005 Nov 19;366(9499):1809-20. Pubmed PMID: 16298220.

[22]. Priyanka S, Kaarthikeyan G, Nadathur JD, Mohanraj A, Kavarthapu A. Detection of cytomegalovirus, Epstein-Barr virus, and Torque Teno virus in subgingival and atheromatous plaques of cardiac patients with chronic periodontitis. J Indian Soc Periodontol. 2017 Nov-Dec;21(6):456-460. Pubmed PMID: 29551863.

[23]. Pussinen PJ, Jousilahti P, Alfthan G, Palosuo T, Asikainen S, Salomaa V. Antibodies to periodontal pathogens are associated with coronary heart disease. Arterioscler Thromb Vasc Biol. 2003 Jul 1;23(7):1250-4. Pubmed PMID: 12714435.

[24]. Pussinen PJ, Nyyssönen K, Alfthan G, Salonen R, Laukkanen JA, Salonen JT. Serum antibody levels to Actinobacillus actinomycetemcomitans predict the risk for coronary heart disease. Arterioscler Thromb Vasc Biol. 2005 Apr;25(4):833-8. Pubmed PMID: 15692101.

[25]. Pussinen PJ, Tuomisto K, Jousilahti P, Havulinna AS, Sundvall J, Salomaa V. Endotoxemia, immune response to periodontal pathogens, and systemic inflammation associate with incident cardiovascular disease events. Arterioscler Thromb Vasc Biol. 2007 Jun;27(6):1433-9. Pubmed PMID: 17363692.

[26]. Ramamurthy, J. and Mg, V. (2018) 'COMPARISON OF EFFECT OF HIORA MOUTHWASH VERSUS CHLORHEXIDINE MOUTHWASH IN GINGIVITIS PATIENTS: A CLINICAL TRIAL', Asian J Pharm Clin Res, 11(7), pp. 84-88.

[27]. Ramesh, A., Varghese, S. S., et al. (2016) 'Chronic obstructive pulmonary disease and periodontitis - unwinding their linking mechanisms', Journal of Oral Biosciences, pp. 23-26. doi: 10.1016/j.job.2015.09.001.

[28]. Ramesh A, Varghese SS, Doraiswamy JN, Malaiappan S. Herbs as an antioxidant arsenal for periodontal diseases. J Intercult Ethnopharmacol. 2016 Jan 27;5(1):92-6. Pubmed PMID: 27069730.

[29]. Ramesh A, Vellayappan R, Ravi S, Gurumoorthy K. Esthetic lip repositioning: A cosmetic approach for correction of gummy smile - A case series. J Indian Soc Periodontol. 2019 May-Jun;23(3):290-294. Pubmed PMID: 31143013.

[30]. Ramesh A, Ravi S, Kaarthikeyan G. Comprehensive rehabilitation using dental implants in generalized aggressive periodontitis. J Indian Soc Peri- odontol. 2017 Mar-Apr;21(2):160-163. Pubmed PMID: 29398863.

[31]. Ravi S, Malaiappan S, Varghese S, Jayakumar ND, Prakasam G. Additive Effect of Plasma Rich in Growth Factors With Guided Tissue Regeneration in Treatment of Intrabony Defects in Patients With Chronic Periodontitis: A Split-Mouth Randomized Controlled Clinical Trial. J Periodontol. 2017 Sep;88(9):839-845. Pubmed PMID: 28474968.

[32]. Ridker PM, Hennekens CH, Buring JE, Rifai N. C-reactive protein and other markers of inflammation in the prediction of cardiovascular disease in women. N Engl J Med. 2000 Mar 23;342(12):836-43. Pubmed PMID: 10733371.

[33]. Sanz, M. et al. (2020) 'Periodontitis and Cardiovascular Diseases. Consensus Report', Global heart, 15(1), p. 1.

[34]. Scannapieco FA. Position paper of The American Academy of Periodontology: periodontal disease as a potential risk factor for systemic diseases. J Periodontol. 1998 Jul;69(7):841-50. Pubmed PMID: 9706864.

[35]. Shiau HJ, Reynolds MA. Sex differences in destructive periodontal disease: a systematic review. J Periodontol. 2010 Oct;81(10):1379-89. Pubmed PMID: 20450376.

[36]. Stewart R, West M. Increasing Evidence for an Association Between Periodontitis and Cardiovascular Disease. Circulation. 2016 Feb 9;133(6):54951. Pubmed PMID: 26762522.

[37]. Thamaraiselvan M, Elavarasu S, Thangakumaran S, Gadagi JS, Arthie T. Comparative clinical evaluation of coronally advanced flap with or without platelet rich fibrin membrane in the treatment of isolated gingival recession. J Indian Soc Periodontol. 2015 Jan-Feb;19(1):66-71. Pubmed PMID: 25810596.

[38]. Varghese SS, Thomas H, Jayakumar ND, Sankari M, Lakshmanan R. Estimation of salivary tumor necrosis factor-alpha in chronic and aggressive periodontitis patients. Contemp Clin Dent. 2015 Sep;6(Suppl 1):S152-6. Pubmed PMID: 26604566.

[39]. Wakai K, Kawamura T, Umemura O, Hara Y, Machida J, Anno T, et al. Associations of medical status and physical fitness with periodontal disease. J Clin Periodontol. 1999 Oct;26(10):664-72. Pubmed PMID: 10522778. 